\title{
Role of Peroxisome Proliferator-Activated Receptor $\beta / \delta$ and B-Cell Lymphoma-6 in Regulation of Genes Involved in Metastasis and Migration in Pancreatic Cancer Cells
}

\author{
Jeffrey D. Coleman, ${ }^{1}$ Jerry T. Thompson, ${ }^{1}$ Russell W. Smith III, \\ Bogdan Prokopczyk, ${ }^{2,3}$ and John P. Vanden Heuvel ${ }^{1,3,4}$ \\ ${ }^{1}$ Department of Veterinary and Biomedical Sciences and Center for Molecular Toxicology and Carcinogenesis, \\ Penn State University, 325 Life Sciences Building, University Park, PA 16802, USA \\ ${ }^{2}$ Department of Pharmacology, Penn State University, Hershey, PA 17033, USA \\ ${ }^{3}$ Penn State Cancer Institute, Hershey, PA 17033, USA \\ ${ }^{4}$ Indigo Biosciences Inc., State College, PA 16801, USA \\ Correspondence should be addressed to John P. Vanden Heuvel; jpv2@psu.edu
}

Received 9 January 2013; Revised 18 March 2013; Accepted 7 April 2013

Academic Editor: Annamaria Cimini

Copyright (C) 2013 Jeffrey D. Coleman et al. This is an open access article distributed under the Creative Commons Attribution License, which permits unrestricted use, distribution, and reproduction in any medium, provided the original work is properly cited.

\begin{abstract}
$P P A R \beta / \delta$ is a ligand-activated transcription factor that regulates various cellular functions via induction of target genes directly or in concert with its associated transcriptional repressor, $B C L-6$. Matrix remodeling proteinases are frequently over-expressed in pancreatic cancer and are involved with metastasis. The present study tested the hypothesis that $P P A R \beta / \delta$ is expressed in human pancreatic cancer cells and that its activation could regulate $M M P-9$, decreasing cancer cells ability to transverse the basement membrane. In human pancreatic cancer tissue there was significantly higher expression of $M M P-9$ and $P P A R \beta / \delta$, and lower levels of $B C L-6$ mRNA. PPAR $\beta / \delta$ activation reduced the TNF $\alpha$-induced expression of various genes implicated in metastasis and reduced the invasion through a basement membrane in cell culture models. Through the use of short hairpin RNA inhibitors of $P P A R \beta / \delta$, $B C L-6$, and $M M P-9$, it was evident that $P P A R \beta / \delta$ was responsible for the ligand-dependent effects whereas $B C L-6$ dissociation upon GW501516 treatment was ultimately responsible for decreasing MMP-9 expression and hence invasion activity. These results suggest that $P P A R \beta / \delta$ plays a role in regulating pancreatic cancer cell invasion through regulation of genes via ligand-dependent release of $B C L-6$ and that activation of the receptor may provide an alternative therapeutic method for controlling migration and metastasis.
\end{abstract}

\section{Introduction}

Pancreatic cancer is the fourth leading cause of cancer-related deaths of men and women in the United States. The American Cancer Society estimates for 2009 predicted approximately 42,470 new cases of pancreatic cancer and that 35,240 of those cases would result in death. Lack of identifiable symptoms or biomarkers combined with a $4 \%$ five-year survival rate makes pancreatic cancer one of the deadliest malignancies [1]. Although pancreatic cancer is difficult to detect in its early stages, several known risk factors exist, with smoking being the most well-documented etiologic agent [2]. Several other risk factors include age, diets high in fat [3], excessive alcohol consumption [4], diabetes mellitus [5], and chronic pancreatitis [6]. Common chemotherapeutic treatments have had little success in improving survival rates or restraining the highly metastatic malignancies [7] with the median survival rate of less than six months and surgical resection as the only effective treatment [8]. Prevention strategies and alternative treatments for pancreatic cancer are sorely needed.

Peroxisome proliferator-activated receptor- $\beta / \delta(P P A R \beta /$ $\delta$ ) is a member of the nuclear receptor superfamily of ligand-activated transcription factors. The PPARs consist of three isoforms: PPAR $\alpha$ (NR1C1), PPAR $\beta / \delta$ (NR1C2; NUC1; 
FAAR fatty acid-activated receptor), and PPAR (NR1C3). The PPARs effect gene transcription in response to various stimuli, such as fatty acids and their metabolites, xenobiotics and isoform-specific drugs, through a heterodimerization with retinoid $X$ receptors $(R X R s)$ and subsequent recognition and binding to peroxisome proliferator-responsive elements (PPREs) within the promoter regions of target genes $[9,10]$. $P P A R \beta / \delta$, unlike PPAR $\alpha$ or PPAR $\gamma$ which have distinct tissue expression patterns and synthetic ligands, is ubiquitously expressed, often at higher levels than the other isoforms. This receptor regulates fatty acid oxidation and lipid homeostasis [11], cell proliferation and differentiation [12], cell survival [13], and the inflammatory response [14]. The latter response may be via its association with the transcriptional repressor $B C L-6$, which is released upon activation of $P P A R \beta / \delta$ [15]. In the pancreas, $P P A R \beta / \delta$ is expressed in islet cells to a greater extent than either PPAR $\alpha$ or PPAR $\gamma$ and in beta cells where it regulates the inflammatory response [16]. Expression profiling analyses in the mouse demonstrated high $P P A R \beta / \delta$ expression in the cytoplasm of delta cells of the islet of Langerhans, suggesting a potential role for the receptor in the regulation of glucose metabolism [17]. Pancreatic ductal adenocarcinomas are by far the most common of pancreatic malignancies [18], and the role(s) of $P P A R \beta / \delta$ in pancreatic ductal cells is poorly understood.

The matrix metalloproteinases are a family of zincdependent proteolytic enzymes that degrade extracellular matrix (ECM) proteins and are well-known regulators of pancreatic cancer cell metastasis and invasion $[19,20]$. Matrix metalloproteinase-9 (MMP-9, also known as gelatinase $\mathrm{B})$ in particular is highly expressed in both clinical and experimental models of pancreatic cancer [21]. Furthermore, pancreatic cancer cells display extremely high basal $M M P-9$ expression, which is further inducible by phorbol 12-myristate 13-acetate (PMA) [22]. Recently, several studies have linked $P P A R \beta / \delta$ to $M M P-9$; in $P P A R \beta / \delta$ null macrophages, basal $M M P-9$ expression is reduced [15], and in vascular smooth muscle cells (VSMCs) $P P A R \beta / \delta$ activation suppressed the expression of both $M M P-2$ and $M M P-9$, with further inhibition on VSMC migration and proliferation [23].

The role(s) of PPARs, particularly $P P A R \beta / \delta$, in tumorigenesis and cancer cell invasion remains controversial. For example, inhibition of PPAR $\gamma$ suppressed pancreatic cancer cell motility in Capan-1 and Panc-1 cells [24], while its activation in AsPC-1 cells by the specific ligand rosiglitazone increased levels of the tumor suppressor PTEN and decreased levels of phosphorylated Akt [25] and induced caspasemediated apoptosis in Miapaca-2 cells [26]. $P P A R \beta / \delta$ is an APC-regulated target of nonstreroidal anti-inflammatory drugs (NSAIDs), suggesting that NSAIDs inhibit tumorigenesis via $P P A R \beta / \delta$ inhibition [27], and genetic disruption of $P P A R \beta / \delta$ contributes to the growth-inhibitory effects of APC [28]. Opposing evidence exists suggesting that $P P A R \beta / \delta$ activation increases [29-31] and decreases cell proliferation [32, $33]$ in various cell types. Previous evidence, however, establishes a clear link between $P P A R \beta / \delta, B C L-6$, and $M M P-9$, and we sought to elucidate the role(s) of $P P A R \beta / \delta$ activation on potential target genes involved in pancreatic cancer invasion and metastasis. The $P P A R \beta / \delta$-specific activator GW501516 and shRNAs to decrease expression of $P P A R \beta / \delta, B C L-6$, and $M M P-9$ were used in two human pancreatic cancer cell lines, Miapaca-2 (COX-2 negative) and BxPc-3 (COX-2 positive). The experiments show that ligand-dependent activation of $P P A R \beta / \delta$ causes a $B C L 6$-dependent repression of MMP-9 and other genes involved in cancer metastasis and decreases indices of cell migration, suggesting that $P P A R \beta / \delta$ agonists may be a beneficial tool in the prevention and treatment of pancreatic cancer.

\section{Materials and Methods}

2.1. Cells and Reagents. Human pancreatic cancer cells, Miapaca-2 (COX-2 negative, CRL-1420) and BxPc-3 (COX-2 positive, CRL-1687), were purchased from the ATCC (Manassas, VA) and cultured in high-glucose DMEM containing $10 \% \mathrm{FBS}$ and $1 \%$ penicillin/streptomycin in a humidified atmosphere at $37^{\circ} \mathrm{C}$ containing $5 \% \mathrm{CO}_{2}$. Human embryonic kidney 293 cells were cultured in DMEM containing 10\% FBS and 1\% penicillin/streptomycin. All media components and fetal bovine serum (FBS) were purchased from Gibco BRL/Life Technologies (Carlsbad, CA). Ciprofibrate (Cipro), purchased from Sigma Chemical Co. (St Louis, MO), was used as the positive control for PPAR $\alpha$. GW501516 (GW), purchased from Sigma Chemical Co., was used as the positive control for $P P A R \beta / \delta$. Rosiglitazone (rosi), purchased from Cayman Chemicals (Ann Arbor, MI), was used as the positive control for PPAR $\gamma$. Recombinant human $T N F \alpha$ and human MMP-9 ELISAs were purchased from Invitrogen (Carlsbad, CA) and used according to the manufacturer's instructions. Human pancreatic cancer, chronic pancreatitis, and pancreas tissue samples were obtained from Dr. Gerhard Leder, (Abt. Allgemein-und Viszeralchirurgie, St. Josef Hospital-Klinikum der Ruhr, University of Bochum, Germany). MISSION shRNA bacterial glycerol stocks targeted against human $P P A R \beta / \delta, B c l 6, M M P$-9, as well as the nontargeting vector, were purchased directly from SigmaAldrich. High Capacity cDNA Archive Kit and ABI7300 realtime PCR system were purchased from Applied Biosystems (Foster City, CA). The pPACKH1 packaging plasmids were kindly provided by Dr. Curtis J. Omiecinski (Penn State University). CytoSelect 96-well cell invasion assay (basement membrane, fluorometric format) was purchased from Cell Biolabs, Inc. (San Diego, CA) and used according to the manufacturer's instructions.

2.2. Isolation of Total RNA and Real-Time Quantitative RT$P C R$. Total RNA was isolated from Miapaca-2 and BxPc-3 cells using Tri-Reagent and the manufacturer's recommended protocol (Sigma). Human pancreatic tissue samples were briefly homogenized in $1 \mathrm{~mL}$ Tri-Reagent, and total RNA was isolated. One $\mu \mathrm{g}$ of total RNA was reverse-transcribed using the High Capacity cDNA Archive Kit (Applied Biosystems, Foster City, CA). PCR primers for quantitative real-time RT-PCR were designed based on published sequences in GenBank and are shown in Table 1 in Supplementary Material available online at http://dx.doi.org/10.1155/2013/121956. The housekeeping gene $\beta$-actin was used to normalize all the 
tested genes. The data shown are representative of three independent experiments with triplicate samples.

2.3. Quantification of MMP-9 Protein by ELISA. MMP-9 protein levels were quantified using the human MMP-9 ELISA according to the manufacturer's instructions (Invitrogen). Briefly, control Miapaca-2 cells or shRNA knockdown cells were plated in 6-well tissue culture plates and treated with $1 \mathrm{ng} / \mathrm{mL} \mathrm{TNF} \alpha$ with or without $500 \mathrm{nM} \mathrm{GW} 501516$ for $24 \mathrm{~h}$. At the end of the incubation time, the media was removed and diluted 1:40 in standard diluent buffer. Diluted media samples and $M M P-9$ standards were added to a 96-well microtiter plate containing human MMP-9 antibody-coated wells and allowed to incubate at room temperature for $2 \mathrm{~h}$. Following the incubation, the media was aspirated and each well washed 5 times with wash buffer. One hundred $\mu \mathrm{L}$ Biotinylated anti-MMP-9 (biotin conjugate) solution was added to each well, and the plate was incubated for $1 \mathrm{~h}$ at room temperature. Each well was washed a second time with wash buffer, and $100 \mu \mathrm{L}$ of streptavidin-HRP working solution was added and the plate was allowed to incubate at room temperature for 30 minutes. After a third wash, $100 \mu \mathrm{L}$ of stabilized chromogen was added to each well, and the plate was incubated at room temperature for 30 minutes in the dark, after which time $100 \mu \mathrm{L}$ of stop solution was added and the absorbance read at $450 \mathrm{~nm}$.

2.4. Cell Migration Assay. Either control or knockdown human pancreatic cancer cells were grown to confluence in $10 \mathrm{~cm}$ tissue culture plates and then pretreated with $T N F \alpha$ with or without GW501516 for $24 \mathrm{~h}$, as above. Cell migration assays were performed using the CytoSelect 96-well cell invasion assay (basement membrane, fluorometric format) according to the manufacturer's instructions. Briefly, the basement membrane was allowed to reach room temperature for 30 minutes and rehydrated using warm, serum-free DMEM. Human pancreatic cancer cells were then seeded into each well at a density of $2 \times 10^{6}$ cells $/ \mathrm{mL}$ in serumfree media. Normal cell media (DMEM containing $10 \%$ FBS, along with $T N F \alpha$ with or without GW501516) was added to the feeder tray, and the entire apparatus was placed in an incubator at $37^{\circ} \mathrm{C}$ containing $5 \% \mathrm{CO}_{2}$ for $24 \mathrm{~h}$. CyQuant GR dye/lysis buffer solution was added to the invading cells following completion of the assay, and the resulting mixture was incubated at room temperature for 20 minutes. Invading cells were quantified by reading the fluorescence at $480 \mathrm{~nm} / 520 \mathrm{~nm}$. All measurements were performed in triplicate.

2.5. Lentiviral shRNA Infection. HEK-293 cells were grown to confluency in $10 \mathrm{~cm}$ tissue culture plates under the conditions described above. The cells were then transiently transfected with $4.6 \mu \mathrm{g}$ of either nontargeting shRNA or shRNAs targeted against human $P P A R \beta / \delta, B C L-6$, or $M M P-9$, as well as $2.4 \mu \mathrm{g}$ each of pPACKH1 packaging plasmids, using Lipofectamine 2000. Cells were transfected for $6 \mathrm{~h}$ and allowed to recover overnight in normal media. Fresh media was added the following morning, and pseudoviral supernatant was generated for $72 \mathrm{~h}$. Supernatant was then harvested and passed through a $0.4 \mu \mathrm{m}$ filter under sterile conditions. Polybrene (Millipore, Billerica, MA) was then added to a final concentration of $5 \mu \mathrm{g}$ per $\mathrm{ml}$, and the pseudoviral supernatant was then added directly to target cells for $6 \mathrm{~h}$. Infected cells were allowed to recover overnight following the addition of $6 \mathrm{~mL}$ complete media, and knockdown of target genes was assessed by RTPCR 48 h postinfection.

2.6. Statistical Analysis. Quantitative data are presented as mean \pm SEM. ANOVA with $P$-value $<0.05$ was used to determine whether differences among variables were significant. Normality was checked using Anderson-Darling test and the general linear model, followed by the Tukey post hoc test to analyze differences between treatments. All data analyses were performed by MiniTAB Ver.14 (MiniTAB, State College, PA) or JMP (SAS Institute, Cary, NC), and data were plotted by Prism 5.01 (GraphPad Software, San Diego, CA).

\section{Results}

3.1. Tissue Samples from Human Pancreatic Ductal Carcinomas Show Significantly Increased Levels of MMP-9 mRNA. It is well known that the matrix metalloproteinases are key regulators of cell proliferation and migration in human pancreatic cancer cells [34] and that MMP-9 protein is increased in the pancreatic juice from patients diagnosed with pancreatic ductal adenocarcinomas [35]. Recently, $M M P-9$ has been linked to $P P A R \beta / \delta$ and the transcriptional repressor $B C L-6$; in $P P A R \beta / \delta^{-/-}$macrophages, for example, there was lower MMP-9 expression compared with wild-type cells [15]. Tissue samples from patients diagnosed with chronic pancreatitis or pancreatic cancer were obtained, and we set out to assess the differences in expression of several genes involved in inflammation and metastasis. Indeed, there was a 10 -fold increase in $M M P-9$ gene expression in ductal carcinomas compared with samples from patients diagnosed with chronic pancreatitis (Figure 1). Interestingly, $P P A R \beta / \delta$ expression was also elevated while mRNA expression of the transcriptional repressor BCL-6 was almost 3-fold lower in tumor samples compared with those from chronic pancreatitis patients. Despite the low expression of $B C L-6$ in ductal carcinomas, the relative expression of two $B C L-6$ target genes, $V C A M-1$ [36] and MCP-1, was not significantly elevated in tumor samples. A $P P A R \beta / \delta$ target gene, $A D R P$, was also not different between tumor, pancreatitis, and other pancreatic tissue samples (data not shown).

\subsection{Regulation of MMP-9 Expression by $P P A R \beta / \delta$ and} $B C L 6$ in Pancreatic Cancer Cells. PPAR $\beta / \delta$ activation negatively influences $M M P-9$ gene expression in $I L-1 \beta$-stimulated vascular smooth muscle cells [23]. To study the mechanism of this response and to determine its applicability to another cell type, Miapaca-2 cells were transiently infected with nontargeting control, $h B C L-6, h P P A R \beta / \delta$, or $h M M P 9$ lentiviral shRNAs (Figure 2(a)). Cells transiently infected with nontargeting control shRNA showed no alterations in either $B C L-6, P P A R \beta / \delta$, or MMP9 mRNA expression. Miapaca cells infected with an shRNA targeted against $B C L-6$ 


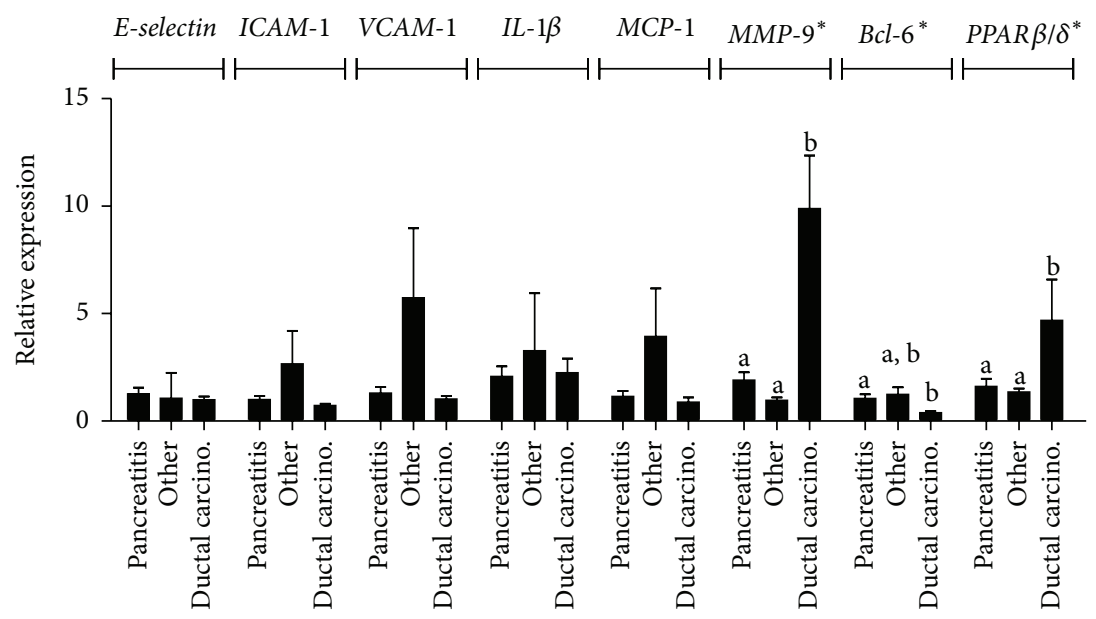

FIGURE 1: Relative mRNA expression in human pancreatic tissues at varying stages of carcinogenesis from chronic pancreatitis to pancreatic cancer. Total mRNA was isolated using standard Tri-Reagent protocol and reverse-transcribed. Gene expression was determined using qRTPCR and expressed as fold induction after normalization to $\beta$-actin. ${ }^{*} P<0.05$.

showed approximately $50 \%$ reduction in BCL-6 mRNA levels, and cells infected with an shRNA targeting $P P A R \beta / \delta$ or $M M P 9$ showed approximately $70 \%$ reduction in corresponding mRNA levels (Figure 2(a)). To determine if gene expression is altered after lentiviral-mediated $B C L-6$ or $P P A R \beta / \delta$ repression, the PPAR target gene $A D R P$ was examined upon treatment with three isoform-specific $P P A R$ agonists (ciprofibrate, PPAR $\alpha$; GW501516, $P P A R \beta / \delta$; rosiglitazone, $P P A R \gamma)$. Control cells and those transiently expressing the indicated shRNAs were treated with either $20 \mu \mathrm{M}$ ciprofibrate, $500 \mathrm{nM}$ GW501516, or $10 \mu \mathrm{M}$ rosiglitazone. Miapaca- 2 cells contain functional PPARs as indicated by the ligand-induced expression of $A D R P$, with each treatment resulting in a threefold increase in transcript levels (Figure 2(b)). Cells expressing $P P A R \beta / \delta$-specific shRNA did not induce expression of $A D R P$ in response to GW501516 at a concentration that activates only $P P A R \beta / \delta$ [37], while cells expressing BCL-6targeting shRNA retained inducible expression of $A D R P$ by all three isoform-specific ligands. Following $B C L-6, P P A R \beta / \delta$ or MMP-9 knockdown, cells were treated with $1 \mathrm{ng} / \mathrm{mL} T N F \alpha$ with or without $500 \mathrm{nM}$ GW501516 for 24 hours, and MMP-9 protein levels were assessed by ELISA. MMP-9 protein levels were significantly elevated in BCL-6 knockdown Miapaca2 cells following $T N F \alpha$ challenge compared with control cells, while $P P A R \beta / \delta$ knockdown Miapaca- 2 cells showed a significant reduction in $T N F \alpha$-induced $M M P$-9 protein levels (Figure 2(c)), consistent with previous reports in $P P A R \beta / \delta^{-/-}$ macrophages. While GW501516 cotreatment significantly suppressed $T N F \alpha$-induced $M M P-9$ protein levels in control (nontargeting) Miapaca-2 cells, this effect was not observed in either of the $B C L-6$ or $P P A R \beta / \delta$ knockdown cells. Not unexpectedly, lentiviral shRNA targeted against $M M P-9$ significantly reduced both mRNA and protein expression in Miapaca-2 cells, and GW501516 activation of $P P A R \beta / \delta$ did not further reduce $M M P-9$ protein levels in these cells.

3.3. MMP-9 Knockdown Reduces Miapaca-2 Cell Invasion. Because MMP-9 is a key regulator of human pancreatic cancer cell invasion and metastasis, we further examined the effect of lentiviral shRNA-mediated $M M P-9$ knockdown on the basal ability of Miapaca-2 cells to invade a basement membrane. Miapaca-2 cells treated with non-targeting control or MMP-9-targeting lentiviral shRNAs were seeded into a 96-well invasion plate and allowed to migrate across a membrane for 24 hours. Using the migration assay described, we found that MMP-9 knock-down significantly reduced the basal migration of Miapaca-2 cells (Figure 2(d)).

3.4. PPAR $\beta / \delta$ Activation Decreases TNF $\alpha$-Induced Expression of Proinflammatory and Cell Adhesion Genes in Human Pancreatic Cancer Cells. PPAR $\beta / \delta$ associates with the transcriptional repressor $B C L-6$ which, upon $P P A R \beta / \delta$ activation, is released and decreases expression of target genes. To determine if the $P P A R \beta / \delta / B C L-6$ pathway is active in human pancreatic cancer cells, we used shRNA knock-down of $P P A R \beta / \delta$ and $B C L-6$ in conjunction with $P P A R \beta / \delta$-specific activation by GW501516 to analyze the gene expression changes. Miapaca-2 cells transiently expressing non-targeting control shRNA, or shRNAs targeted against $P P A R \beta / \delta$ or $B C L-6$, were stimulated with $1 \mathrm{ng} / \mathrm{mL} T N F \alpha$ with or without GW501516 for 24 hours. In control Miapaca- 2 cells, TNF $\alpha$ stimulation induced the robust expression of the cell adhesion molecules E-selectin, ICAM-1 and VCAM-1, the proinflammatory genes $I L-1 \beta$ and $M C P-1$, and the promigratory gene MMP-9, while cotreatment with 500 nM GW501516 significantly suppressed their expression at the mRNA level (Figure 3). Treatment of Miapaca-2 cells with a BCL-6targeting shRNA attenuated the GW501516 inhibitory effect on the genes tested, indicating a role for BCL-6 in GW501516mediated repression. Consistent with the findings of Lee et al. in $P P A R \beta / \delta^{-/-}$RAW264.7 macrophage cells, $P P A R \beta / \delta$ knock-down Miapaca-2 cells displayed significantly lower levels of these genes when challenged with $T N F \alpha$ alone, and $P P A R \beta / \delta$ activation with GW501516 had no further significant repressive effect. Of note is the fact that although $B C L$ 6 repression resulted in increased $M M P-9$ protein levels in 


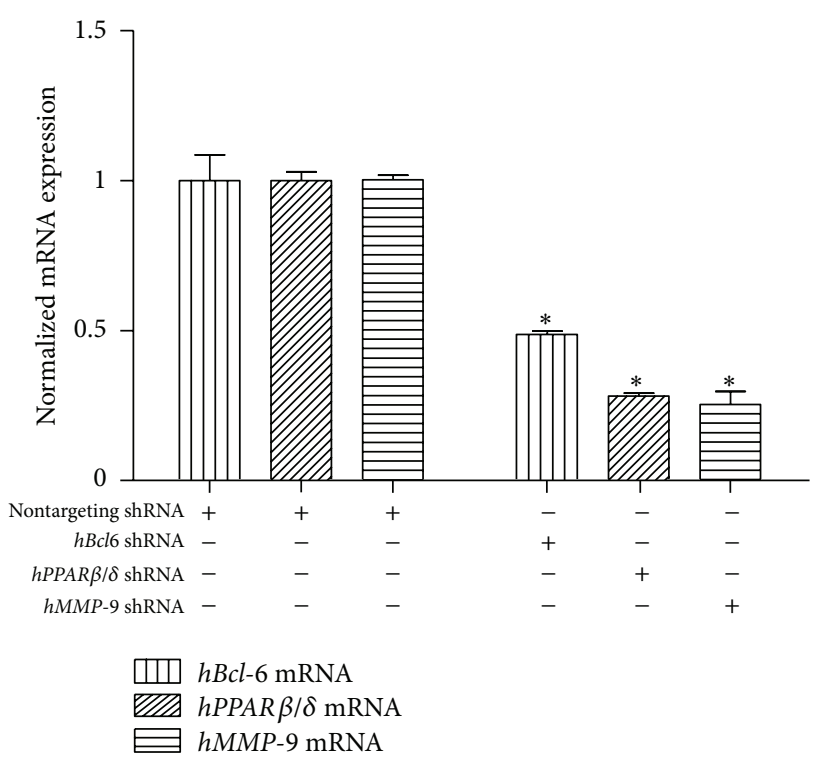

(a)

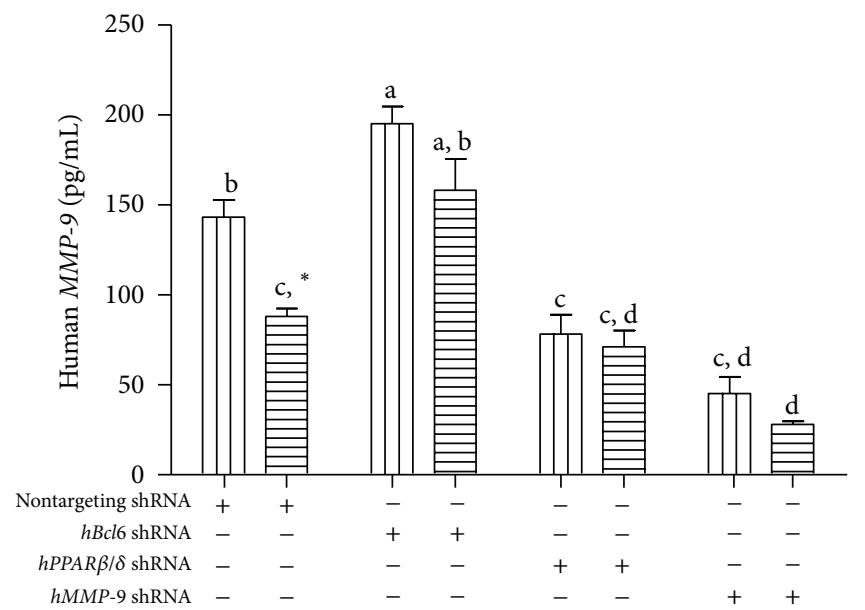

$T N F \alpha$

$T N F \alpha+$ GW501516

(c)

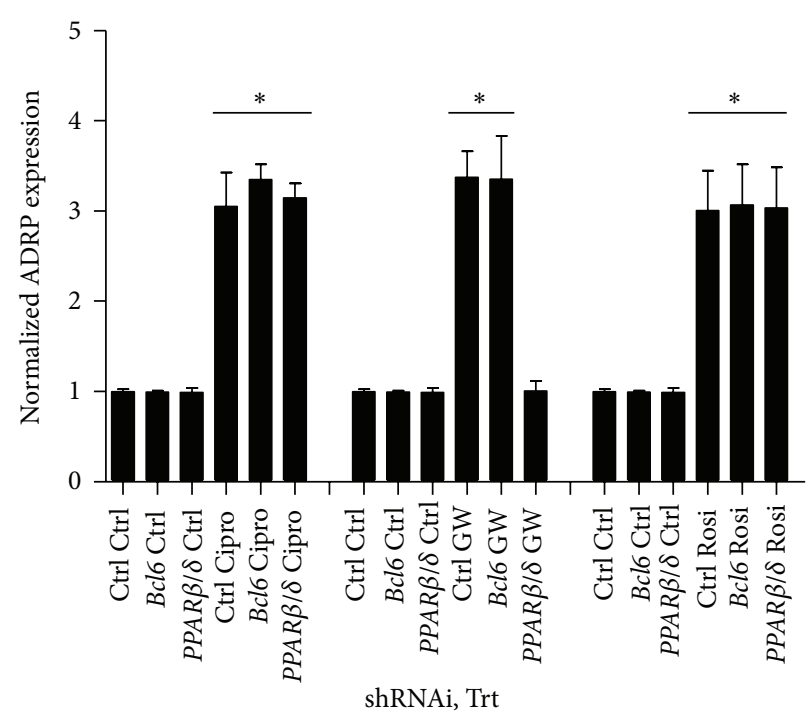

(b)

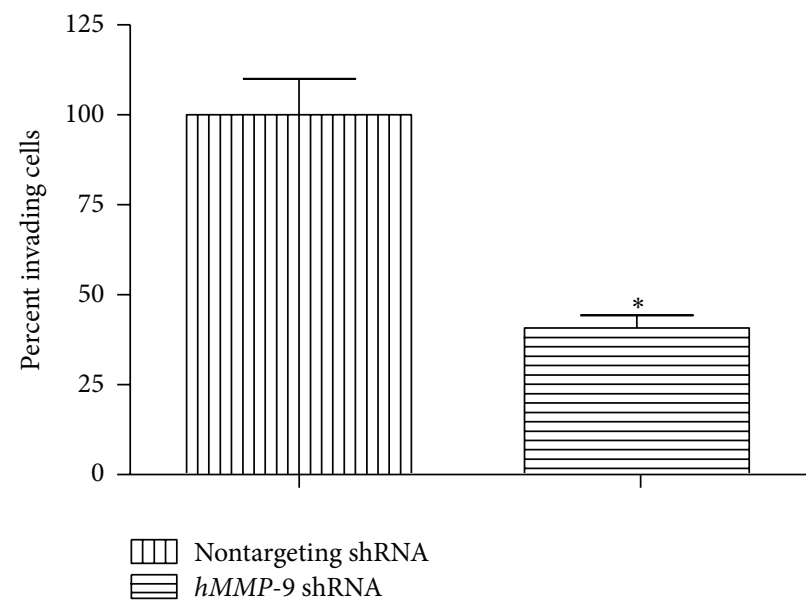

Figure 2: Effect of $P P A R \beta / \delta$ activation on $M M P$-9 expression. (a) Miapaca-2 cells were transiently infected with nontargeting control, $h B C L$ $6, h P P A R \beta / \delta$, or $h M M P 9$ lentiviral shRNAs for 48 hours. Total mRNA was isolated and gene-specific knockdown was assessed using qRTPCR. ${ }^{*} P<0.05$. (b) Miapaca-2 cells contain functional PPARs. Miapaca-2 cells were transiently infected with the indicated shRNAs and treated with the indicated PPAR isoform-specific agonists. Induction of the PPAR-target gene ADRP was determined using $\mathrm{qRT}$-PCR. ${ }^{*} P<$ 0.05. (c) Miapaca-2 cells were stimulated with human TNF $\alpha$ with or without GW501516 for 24 hours following transient infection with the indicated shRNAs. Human $M M P-9$ protein expression was quantified using $M M P$-9-specific ELISA (Invitrogen). ${ }^{*} P<0.05$. (d) Miapaca2 cells with reduced $M M P-9$ expression are less invasive than control Miapaca- 2 cells. Following infection with human $M M P-9$-targeting shRNA, Miapaca-2 cells were seeded in 96-well invasion plates (Cell Biolabs, Inc.) and allowed to invade the basement membrane overnight. Relative cell invasion was quantified using the CytoSelect 96 -well cell invasion assay with fluorometric readings at $480 \mathrm{~nm} / 520 \mathrm{~nm}$. ${ }^{*} P<$ 0.05 .

media, it did not concordantly increase the mRNA expression of this gene.

3.5. $P P A R \beta / \delta$ Activation Inhibits Human Pancreatic Cancer Cell Migration. To examine if $P P A R \beta / \delta$ activation by
GW501516 and subsequent repression of pro-inflammatory and pro-migratory genes via $B C L-6$ influenced their ability to invade a basement membrane, Miapaca-2 (COX-2 negative, Figure 4(a)) and BxPc-3 (COX-2 positive, Figure 4(b)) were treated with non-, $P P A R \beta / \delta$ - or $B C L-6$-targeting shRNA, and the effects of GW501516 on cell migration were examined. In 


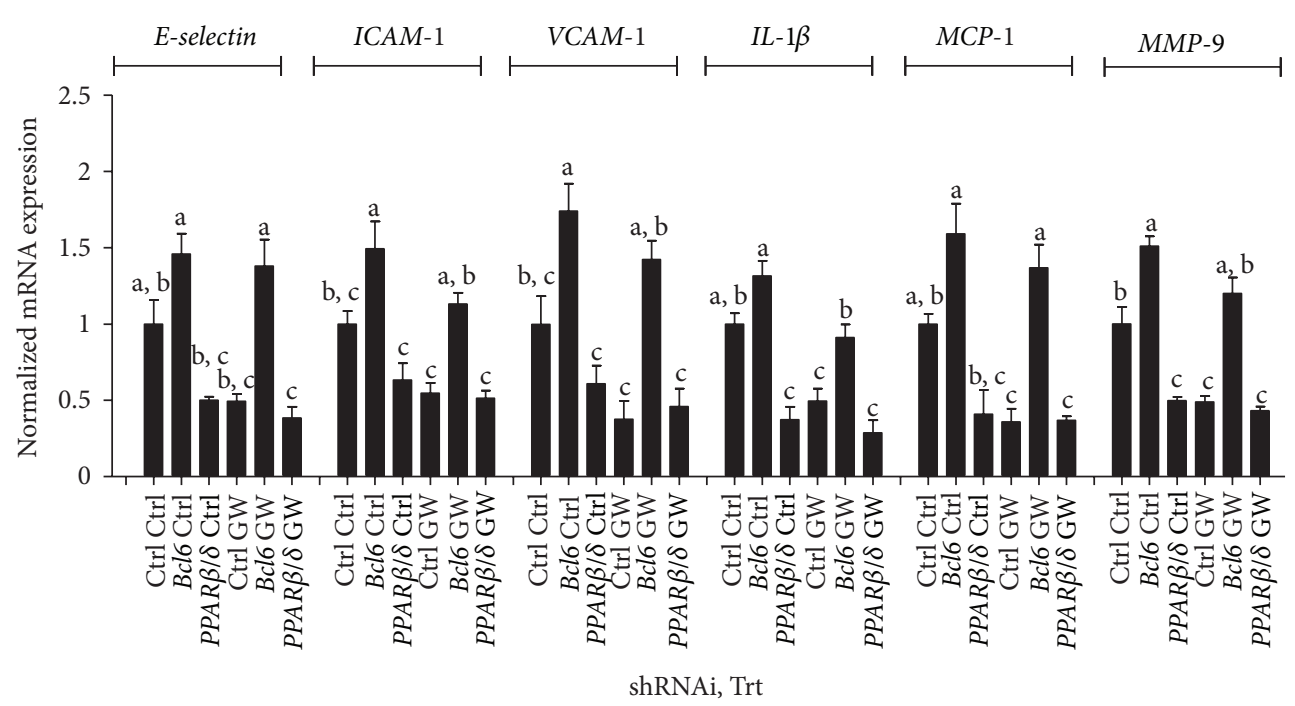

Figure 3: Effects of $P P A R \beta / \delta$ and $B C L-6$ knockdown on Miapaca-2 gene expression. Miapaca-2 cells were transiently infected with nontargeting control, $h B C L-6$ or $h P P A R \beta / \delta$-specific shRNAs and then stimulated with human TNF $\alpha$ with or without GW501516 for 24 hours. Total mRNA was isolated and gene expression was determined using qRT-PCR. Data is normalized to $\beta$-actin and indicated as fold change.

control cells, GW501516 treatment negatively influenced the ability of either Miapaca- 2 or BxPc- 3 cells to migrate across a membrane (50\% reduction). Lentiviral-mediated knockdown of $B C L-6$, however, increased cell migration in both cell lines compared with control cells. GW501516 treatment of BCL-6 repressed cells did not have an effect on Miapaca (Figure 4(a)) but did have an effect on comparable BxPc-3 cells (Figure 4(b)). Interestingly, Miapaca- 2 and BxPc-3 cells transiently expressing an shRNA targeted against $P P A R \beta / \delta$ showed significantly reduced cell migration compared with control cells with or without GW501516 treatment. These results suggested that the transcriptional repressor $B C L-6$ mediates the antimigratory actions of GW501516 in human pancreatic cancer cells but does so in a $P P A R \beta / \delta$-dependent manner.

\section{Discussion}

The PPAR nuclear receptors are regulators of inflammation and proliferation in human pancreatic cells [16, 38, 39]. Although several studies implicate $P P A R \gamma$ activation in inhibition of pancreatic cancer cell growth, little is known about the role of $P P A R \beta / \delta$, save for its role in suppressing inflammation via $B C L-6$ [16]. Generally, the role of $P P A R \beta / \delta$ in cancer cell growth and tumorigenesis remains controversial. In colorectal cancer cells, nonsteroidal antiinflammatory drugs inhibit tumorigenesis through inhibition of $P P A R \beta / \delta$ [27], and $P P A R \beta / \delta$ promotes intestinal carcinogenesis [40]. Studies in the $P P A R \beta / \delta$ null mouse, however, show that activation of $P P A R \beta / \delta$ induces terminal differentiation [41], and $P P A R \beta / \delta$-specific ligands inhibit the growth of keratinocytes in vivo $[42,43]$ and in vitro [32]. Furthermore, $P P A R \beta / \delta$ activation is linked to inhibition of $I L-1 \beta$-stimulated proliferation and migration of vascular smooth muscle cells [23] via regulation of $I L-1 R a$ and TGF- $\beta$ and negative regulation of $M M P-9$. Our results show that $P P A R \beta / \delta$ activation by GW501516 suppresses expression of $M M P-9$ in human pancreatic cancer cells via $B C L-6$, with further inhibition on the ability of two cell lines, Miapaca-2 and $\mathrm{BxPc}-3$, to invade a basement membrane.

Consistent with previous work [35], analysis of the expression levels of several genes in both ductal carcinomas and chronic pancreatitis showed elevated levels of the matrixremodeling gene MMP-9. Several studies link increased $M M P-9$ levels to increased invasiveness and metastasis [44, 45]. $M M P-9$ is a critical player in the early stages of tumor invasion by degrading basement membrane type IV collagen [46], considered to be a crucial step in tumor cell invasion [47]. MMP-9 also participates in the degradation of the various components of the ECM [48]. Inhibition of $M M P$ activity by orally bioavailable matrix metalloproteinase inhibitors has shown promise in decreasing tumor metastasis in clinical trials [46]. In the cell lines BxPc-3 and Miapaca-2, treatment with the neurotransmitter norepinephrine increased cell invasiveness via augmented $M M P$ 2, MMP-9, and VEGF [49], while treatment with the $\beta$ blocker propranolol inhibited these effects. Clearly the regulation of $M M P$ activity is important in controlling, and possibly treating, pancreatic cancer. The association between $M M P-9, P P A R \beta / \delta$, and $B C L-6$ was established by Lee et al. [15], demonstrating that $M M P-9$ expression in $P P A R \beta / \delta^{-/}$ macrophages is repressed compared to wild type. Activation of the receptor significantly decreased the expression of proinflammatory markers, suggesting that $B C L-6$ released from the $P P A R \beta / \delta$ complex plays a role in the regulation of $M M P$ 9. A similar result was obtained in VSMCs [23].

In the present studies, $P P A R \beta / \delta$ mRNA were increased in ductal carcinomas, while $B C L-6$ expression was decreased. 


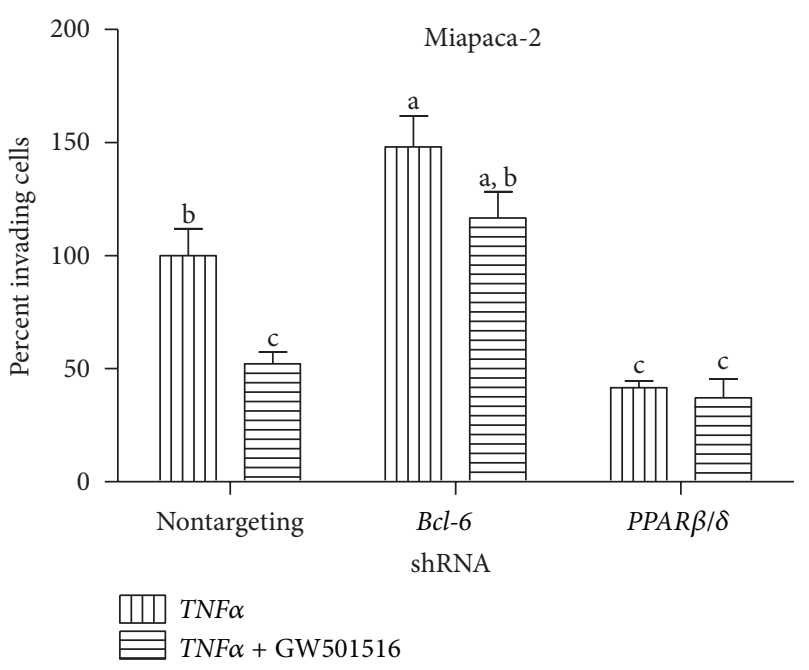

(a)

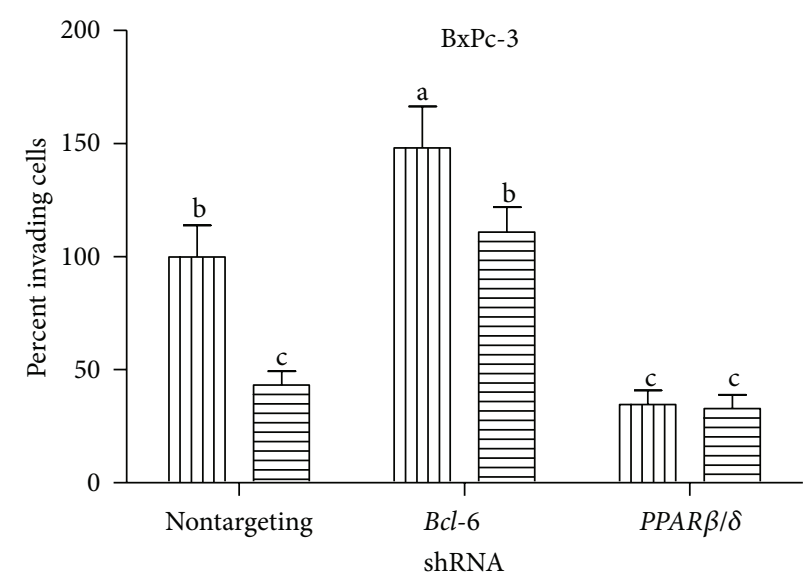

(b)

FIGURE 4: GW501516 treatment reduces TNF $\alpha$-stimulated Miapaca-2 and BxPc-3 cell invasion through a basement membrane. Human pancreatic cancer cells were transiently infected with the indicated shRNAs and stimulated with human TNF $\alpha$ with or without GW501516. Cells were allowed to invade a basement membrane overnight, and relative invasion was quantified using the CytoSelect 96-well cell invasion assay with fluorometric readings at $480 \mathrm{~nm} / 520 \mathrm{~nm}$. GW501516 treatment inhibits the invasion of the COX-2 negative pancreatic cancer cell line Miapaca-2 (a) and the COX-2 positive pancreatic cancer cell line BxPc-3 (b) through a basement membrane.

In colorectal cancer tissue samples, $P P A R \beta / \delta$ expression increased during multistage carcinogenesis and was tightly associated with a highly malignant morphology [50]. It is possible that $P P A R \beta / \delta$ plays a role in human pancreatic cells, but whether $P P A R \beta / \delta$ contributes to pancreatic cancer cell metastasis or if its overexpression is the result of some altered signaling pathway remains unclear. Since the regulatory region of the $P P A R \beta / \delta$ contains several AP- 1 response elements and is controlled by a variety of inflammatory signals [51], the increased expression of this nuclear receptor may be indicative of stress response and not causally related to the tumor phenotype. Increased expression of $P P A R \beta / \delta$ in the inactivated state may sequester $B C L-6$, increasing the expression of genes normally controlled by this transcriptional repressor.

Of particular note is the observation that the relative expression of $B C L-6$, a proto-oncogene known to suppress genes involved in cell cycle progression, particularly cyclin D1 [52], and inflammation [53], was lower in ductal carcinomas compared with pancreatitis. BCL-6 is mutated in several disorders [54-56] and is implicated in cell line immortalization and transformation by overriding cellular senescence downstream of p53 [57]. Interestingly, DNAchip hybridization assays identified both BCL-6 and $B C L$ 10 as novel candidate genes in pancreatic cancer that were overexpressed in pancreatic cancer cell lines and primary tumor samples [58]. Contrary to ductal cells, BCL-6 is absent in pancreatic beta cells, potentially explaining the lack of anti-inflammatory $P P A R \beta / \delta$ signaling in this cell type [16]. Our results suggest that the BCL-6 pathway is disrupted as inflamed tissue transforms into tumor, with the possibility that loss of BCL-6 expression leads to increased cancer invasion via increased $M M P-9$ expression.
Activation of $P P A R \beta / \delta$ decreased the expression of $M M P-9$ at the protein level, while knockdown of $B C L$ 6 increased $M M P-9$ protein production. Activation of $P P A R \beta / \delta$ in $B C L-6$ knock-down cells showed no significant effect on reducing $M M P-9$ protein, suggesting a key role for $B C L-6$ in the regulation of $M M P-9$. Knocking down $P P A R \beta / \delta$ in human pancreatic cancer cells reduced $M M P$ 9 protein levels to those comparable to GW501516-treated control cells despite $P P A R \beta / \delta$ activation. It is our hypothesis that $M M P-9$ is an indirect $P P A R \beta / \delta$ target gene and that $P P A R \beta / \delta$ activation releases $B C L-6$ which may then relocate to the MMP-9 promoter. Further studies, such as chromatin immunoprecipitation assays, for example, are required to substantiate this point. Our results, however, are in agreement with previous work indicating that low levels of $P P A R \beta / \delta$ result in decreased MMP-9 expression [15], and we believe that, in the absence of $P P A R \beta / \delta, B C L-6$ is available to repress target genes, either through direct repression on target gene promoters as in the case of VCAM-1 and E-selectin, two genes lacking PPREs, [36] or through interactions with other cell signaling mediators, such as $N F-\kappa B$ [59]. GW0742 has been found to inhibit inflammation by $T N F-\alpha$ while not preventing $T N F-\alpha$-induced degradation of $I \kappa B \alpha$ and the translocation of $N F \kappa B$. No decrease in DNA binding activity indicates $P P A R \beta / \delta$ must interfere via a corepressors mechanism at the chromatin level [36].

The relationship between $M M P-9$ and metastasis in pancreatic cancer is well documented. Treatment of Miapaca2 cells with MMP-9 shRNA reduced protein levels by approximately 50\% regardless of GW501516 treatment, with corresponding inhibition on the ability of the cell line to invade a basement membrane. Miapaca- 2 cells are considered a highly metastatic cell line [60], and our results support 
the idea that regulating MMP-9 expression may effectively control human pancreatic cancer cell invasion and metastasis.

$P P A R \beta / \delta$ activation is associated with reduced inflammatory and adhesion cell markers. Our results in Miapaca2 cells show that the $P P A R \beta / \delta$ BCL- 6 anti-inflammatory pathway is active and represses E-selectin, ICAM-1, VCAM-1, $I L-1 \beta, M C P-1$, and MMP-9. Repression of VCAM-1, E-selectin, [36], and $M C P-1$ [15] in particular is dependent upon dissociation of $B C L-6$ from $P P A R \beta / \delta$ and subsequent relocation to the corresponding promoters. Our results demonstrate that the proadhesion molecules E-selectin, ICAM-1, and $V C A M-1$, the pro-inflammatory $I L-1 \beta$ and $M C P-1$, and the prometastasis gene $M M P-9$ are $B C L-6$-regulated genes in human pancreatic cancer cells. Treatment with $B C L-6$ shRNA attenuated the GW501516-mediated inhibition of TNF $\alpha$ induced expression of these molecules, while treatment with $P P A R \beta / \delta$ shRNA reduced their expression at the mRNA level regardless of GW501516 treatment. E-selectin, ICAM1 , and VCAM-1 are important in pancreatic cancer, where they participate in the detachment of cells from the primary tumor and contribute to cancer spread [61], and their overexpression in pancreatic adenocarcinomas is associated with a stimulation in tumor growth, increased metastatic ability, and potentially shorter postoperative survival following tumor resection [62]. $I L-1 \beta$ induces $M M P-9$ expression in other cell lines [63-65] and enhances the invasiveness of human pancreatic cancer cells [66]. Monocyte chemotactic protein-1 is produced by pancreatic cancer cells in response to TNF $\alpha$ challenge and may contribute to the accumulation of tumorassociated macrophages [67] which influence key events in the tumor invasion process [68]. Taken together, these results suggest that $P P A R \beta / \delta$ activation and subsequent suppression of proadhesion and pro-migratory genes via BCL-6 might prove useful in the control of pancreatic cancer.

GW501516 treatment also inhibited the TNF $\alpha$-promoted invasion of a basement membrane by the pancreatic ductal cell lines Miapaca-2 and BxPc-3. Pancreatic cancer cells transiently expressing $B C L-6$ shRNA were significantly more invasive, while GW501516 treatment attenuated their invasive potential close to control levels. Conversely, cells transiently expressing $P P A R \beta / \delta$ shRNA were significantly less invasive than control cells, and GW501516 treatment showed no significant effect in further reducing invasion. We hypothesize that cells expressing lower levels of the transcriptional repressor BCL-6 are more invasive owing to a lack of control over pro-migratory gene regulation and increased protein levels of $M M P-9$, while knocking down $P P A R \beta / \delta$ via shRNA methods allow for a greater population of unassociated $B C L-6$ which is available to repress pro-migratory genes resulting in lower invasion. Although we present here a fairly simplified mechanism, it is possible that more complex signaling cascade is taking place resulting in the inhibition of cell invasion. In VSMCs, repression of $M M P-9$ activity was effected in a TGF- $\beta$-dependent manner following $P P A R \beta / \delta$ activation [23], and indeed, TGF- $\beta$ suppresses $M M P-9$ expression in monocytes through a prostaglandin E2- and cAMP-dependent mechanism [69]. TGF- $\beta$ is a $P P A R \beta / \delta$ target gene in VSMCs [70], and it is possible that the PPAR $\beta / \delta-T G F-\beta$ pathway could in fact be active in human pancreatic cancer cells. Our results suggest, however, that $B C L-6$ and $P P A R \beta / \delta$ play critical roles in suppressing pro-migratory gene expression at the mRNA level and in ultimately controlling human pancreatic cancer cell invasion.

Our observations demonstrate that activation of $P P A R \beta / \delta$ by a specific agonist reduces the $T N F \alpha$-induced mRNA levels of genes known to be involved in the regulation of human pancreatic cancer cell invasion and metastasis, and this negative regulation is also manifested at the protein level. Furthermore, we show that $P P A R \beta / \delta$ activation reduces Miapaca- 2 and $\mathrm{BxPc}-3$ invasion through a basement membrane, and that the transcriptional repressor $B C L-6$ plays a critical role in the pathway(s) regulating human pancreatic cancer cell invasion. This is not the first time PPAR activators have been shown to negatively influence pancreatic cancer cell invasion, and perhaps further in vivo studies using these mouse transplantable cell lines could provide more useful insight into the potential therapeutic uses of $P P A R \beta / \delta$ activators in the control and regulation of pancreatic cancer.

\section{Conflict of Interests}

All authors declare no conflict of interests in this study.

\section{References}

[1] A. Maitra and R. H. Hruban, "Pancreatic cancer," Annual Review of Pathology: Mechanisms of Disease, vol. 3, pp. 157-188, 2008.

[2] A. B. Lowenfels and P. Maisonneuve, "Epidemiology and risk factors for pancreatic cancer," Best Practice and Research: Clinical Gastroenterology, vol. 20, no. 2, pp. 197-209, 2006.

[3] D. S. Michaud, S. Liu, E. Giovannucci, W. C. Willett, G. A. Colditz, and C. S. Fuchs, "Dietary sugar, glycemic load, and pancreatic cancer risk in a prospective study," Journal of the National Cancer Institute, vol. 94, no. 17, pp. 1293-1300, 2002.

[4] D. S. Michaud, A. Vrieling, L. Jiao et al., "Alcohol intake and pancreatic cancer: a pooled analysis from the pancreatic cancer cohort consortium (PanScan)," Cancer Causes and Control, vol. 21, no. 8, pp. 1213-1225, 2010.

[5] J. Everhart and D. Wright, "Diabetes mellitus as a risk factor for pancreatic cancer: a meta-analysis," Journal of the American Medical Association, vol. 273, no. 20, pp. 1605-1609, 1995.

[6] S. Raimondi, P. Maisonneuve, and A. B. Lowenfels, "Epidemiology of pancreatic cancer: an overview," Nature Reviews Gastroenterology and Hepatology, vol. 6, no. 12, pp. 699-708, 2009.

[7] T. E. Adrian, "Inhibition of pancreatic cancer cell growth," Cellular and Molecular Life Sciences, vol. 64, no. 19-20, pp. 25122521, 2007.

[8] D. Goldstein, S. Carroll, M. Apte, and G. Keogh, "Modern management of pancreatic carcinoma," Internal Medicine Journal, vol. 34, no. 8, pp. 475-481, 2004.

[9] A. Chawta, J. J. Repa, R. M. Evans, and D. J. Mangelsdorf, "Nuclear receptors and lipid physiology: opening the $\mathrm{x}$-files," Science, vol. 294, no. 5548, pp. 1866-1870, 2001.

[10] T. Lemberger, B. Desvergne, and W. Wahli, "Peroxisome proliferator-activated receptors: a nuclear receptor signaling 
pathway in lipid physiology," Annual Review of Cell and Developmental Biology, vol. 12, pp. 335-363, 1996.

[11] A. Fredenrich and P. A. Grimaldi, "PPAR delta: an uncompletely known nuclear receptor," Diabetes and Metabolism, vol. 31, no. 1, pp. 23-27, 2005.

[12] A. Cimini and M. P. Cerù, "Emerging roles of peroxisome proliferator-activated receptors (PPARs) in the regulation of neural stem cells proliferation and differentiation," Stem Cell Reviews, vol. 4, no. 4, pp. 293-303, 2008.

[13] L. Michalik, B. Desvergne, and W. Wahli, "Peroxisome proliferator-activated receptors $\beta / \delta$ : emerging roles for a previously neglected third family member," Current Opinion in Lipidology, vol. 14, no. 2, pp. 129-135, 2003.

[14] D. Bishop-Bailey and J. Bystrom, "Emerging roles of peroxisome proliferator-activated receptor- $\beta / \delta$ in inflammation," Pharmacology and Therapeutics, vol. 124, no. 2, pp. 141-150, 2009.

[15] C. H. Lee, A. Chawla, N. Urbiztondo, D. Liao, W. A. Boisvert, and R. M. Evans, "Transcriptional repression of atherogenic inflammation: modulation by PPAR $\delta$," Science, vol. 302, no. 5644, pp. 453-457, 2003.

[16] I. Kharroubi, C. H. Lee, P. Hekerman et al., "BCL-6: a possible missing link for anti-inflammatory PPAR- $\delta$ signalling in pancreatic beta cells," Diabetologia, vol. 49, no. 10, pp. 2350-2358, 2006.

[17] H. Higashiyama, A. N. Billin, Y. Okamoto, M. Kinoshita, and S. Asano, "Expression profiling of Peroxisome proliferatoractivated receptor-delta (PPAR-delta) in mouse tissues using tissue microarray," Histochemistry and Cell Biology, vol. 127, no. 5, pp. 485-494, 2007.

[18] S. Pandol, M. Edderkaoui, I. Gukovsky, A. Lugea, and A. Gukovskaya, "Desmoplasia of pancreatic ductal adenocarcinoma," Clinical Gastroenterology and Hepatology, vol. 7, no. 11, pp. S44-S47, 2009.

[19] A. Halbersztadt, A. Haloń, J. Pajak, J. Robaczyński, J. Rabczynski, and M. St Gabryś, "The role of matrix metalloproteinases in tumor invasion and metastasis," Ginekologia Polska, vol. 77, no. 1, pp. 63-71, 2006.

[20] E. I. Deryugina and J. P. Quigley, "Matrix metalloproteinases and tumor metastasis," Cancer and Metastasis Reviews, vol. 25, no. 1, pp. 9-34, 2006.

[21] M. Bloomston, E. E. Zervos, and A. S. Rosemurgy, "Matrix metalloproteinases and their role in pancreatic cancer: a review of preclinical studies and clinical trials," Annals of Surgical Oncology, vol. 9, no. 7, pp. 668-674, 2002.

[22] M. W. Roomi, J. C. Monterrey, T. Kalinovsky, M. Rath, and A. Niedzwiecki, "Patterns of MMP-2 and MMP-9 expression in human cancer cell lines," Oncology Reports, vol. 21, no. 5, pp. 1323-1333, 2009.

[23] H. J. Kim, M. Y. Kim, J. S. Hwang et al., "PPAR $\delta$ inhibits IL$1 \beta$-stimulated proliferation and migration of vascular smooth muscle cells via up-regulation of IL-1Ra," Cellular and Molecular Life Sciences, vol. 67, no. 12, pp. 2119-2130, 2010.

[24] A. Nakajima, A. Tomimoto, K. Fujita et al., "Inhibition of peroxisome proliferator-activated receptor $\gamma$ activity suppresses pancreatic cancer cell motility," Cancer Science, vol. 99, no. 10, pp. 1892-1900, 2008.

[25] B. Farrow and B. M. Evers, "Activation of PPAR $\gamma$ increases PTEN expression in pancreatic cancer cells," Biochemical and Biophysical Research Communications, vol. 301, no. 1, pp. 50-53, 2003.
[26] K. Hashimoto, B. J. Farrow, and B. M. Evers, "Activation and role of MAP kinases in 15d-PGJ2-induced apoptosis in the human pancreatic cancer cell line MIA PaCa-2," Pancreas, vol. 28, no. 2, pp. 153-159, 2004.

[27] T. C. He, T. A. Chan, B. Vogelstein, and K. W. Kinzler, "PPAR $\delta$ is an APC-regulated target of nonsteroidal anti-inflammatory drugs," Cell, vol. 99, no. 3, pp. 335-345, 1999.

[28] B. H. Park, B. Vogelstein, and K. W. Kinzler, "Genetic disruption of PPAR $\delta$ decreases the tumorigenicity of human colon cancer cells," Proceedings of the National Academy of Sciences of the United States of America, vol. 98, no. 5, pp. 2598-2603, 2001.

[29] C. Bastie, "PPAR $\delta$ and PPAR $\gamma$ : roles in fatty acids signalling, implication in tumorigenesis," Bulletin du Cancer, vol. 89, no. 1, pp. 23-28, 2002.

[30] B. Glinghammar, J. Skogsberg, A. Hamsten, and E. Ehrenborg, "PPAR $\delta$ activation induces COX-2 gene expression and cell proliferation in human hepatocellular carcinoma cells," Biochemical and Biophysical Research Communications, vol. 308, no. 2, pp. 361-368, 2003.

[31] M. Romanowska, N. Al Yacoub, H. Seidel et al., "PPAR $\delta$ enhances keratinocyte proliferation in psoriasis and induces heparin-binding EGF-like growth factor," Journal of Investigative Dermatology, vol. 128, no. 1, pp. 110-124, 2008.

[32] A. D. Burdick, M. T. Bility, E. E. Girroir et al., "Ligand activation of peroxisome proliferator-activated receptor- $\beta / \delta(\operatorname{PPAR} \beta / \delta)$ inhibits cell growth of human N/TERT-1 keratinocytes," Cellular Signalling, vol. 19, no. 6, pp. 1163-1171, 2007.

[33] H. E. Hollingshead, R. L. Killins, M. G. Borland et al., "Peroxisome proliferator-activated receptor- $\beta / \delta(\operatorname{PPAR} \beta / \delta)$ ligands do not potentiate growth of human cancer cell lines," Carcinogenesis, vol. 28, no. 12, pp. 2641-2649, 2007.

[34] M. Kilian, J. I. Gregor, I. Heukamp et al., "Matrix metalloproteinase inhibitor RO 28-2653 decreases liver metastasis by reduction of MMP-2 and MMP- 9 concentration in BOP-induced ductal pancreatic cancer in Syrian Hamsters: inhibition of matrix metalloproteinases in pancreatic cancer," Prostaglandins Leukotrienes and Essential Fatty Acids, vol. 75, no. 6, pp. 429-434, 2006.

[35] M. Tian, Y. Z. Cui, G. H. Song et al., "Proteomic analysis identifies MMP-9, DJ-1 and A1BG as overexpressed proteins in pancreatic juice from pancreatic ductal adenocarcinoma patients," BMC Cancer, vol. 8, article 241, 2008.

[36] Y. Fan, Y. Wang, Z. Tang et al., "Suppression of proinflammatory adhesion molecules by PPAR-delta in human vascular endothelial cells," Arteriosclerosis, Thrombosis, and Vascular Biology, vol. 28, no. 2, pp. 315-321, 2008.

[37] R. L. Stephen, M. C. U. Gustafsson, M. Jarvis et al., "Activation of peroxisome proliferator-activated receptor $\delta$ stimulates the proliferation of human breast and prostate cancer cell lines," Cancer Research, vol. 64, no. 9, pp. 3162-3170, 2004.

[38] S. Kawa, T. Nikaido, H. Unno, N. Usuda, K. Nakayama, and K. Kiyosawa, "Growth inhibition and differentiation of pancreatic cancer cell lines by PPAR $\gamma$ ligand troglitazone," Pancreas, vol. 24, no. 1, pp. 1-7, 2002.

[39] G. Eibl, "The role of PPAR- $\gamma$ and its interaction with COX-2 in pancreatic cancer," PPAR Research, vol. 2008, Article ID 326915, 6 pages, 2008 .

[40] G. G. Mackenzie, S. Rasheed, W. Wertheim, and B. Rigas, "NOdonating NSAIDs, PPAR $\delta$, and cancer: does $\operatorname{PPAR} \delta$ contribute 
to colon carcinogenesis?” PPAR Research, vol. 2008, Article ID 919572, 11 pages, 2008.

[41] H. E. Marin, M. A. Peraza, A. N. Billin et al., "Ligand activation of peroxisome proliferator-activated receptor $\beta$ inhibits colon carcinogenesis," Cancer Research, vol. 66, no. 8, pp. 4394-4401, 2006.

[42] D. J. Kim, M. T. Bility, A. N. Billin, T. M. Willson, F. J. Gonzalez, and J. M. Peters, "PPAR $\beta / \delta$ selectively induces differentiation and inhibits cell proliferation," Cell Death and Differentiation, vol. 13, no. 1, pp. 53-60, 2006.

[43] D. J. Kim, K. Sandeep Prabhu, F. J. Gonzalez, and J. M. Peters, "Inhibition of chemically induced skin carcinogenesis by sulindac is independent of peroxisome proliferator-activated receptor- $\beta / \delta(\operatorname{PPAR} \beta / \delta)$," Carcinogenesis, vol. 27, no. 5, pp. 1105-1112, 2006.

[44] X. Yang, E. D. Staren, J. M. Howard, T. Iwamura, J. E. Bartsch, and H. E. Appert, "Invasiveness and MMP expression pancreatic carcinoma," Journal of Surgical Research, vol. 98, no. 1, pp. 33-39, 2001.

[45] M. Maatta, Y. Soini, A. Liakka, and H. Autio-Harmainen, "Differential expression of matrix metalloproteinase (MMP)2, MMP-9, and membrane type 1-MMP in hepatocellular and pancreatic adenocarcinoma: implications for tumor progression and clinical prognosis," Clinical Cancer Research, vol. 6, no. 7, pp. 2726-2734, 2000.

[46] J. D. Evans, P. Ghaneh, A. Kawesha, and J. P. Neoptolemos, "Role of matrix metalloproteinases and their inhibitors in pancreatic cancer," Digestion, vol. 58, no. 6, pp. 520-528, 1997.

[47] C. S. Lee, J. Montebello, T. Georgiou, and J. Rode, "Distribution of type IV collagen in pancreatic adenocarcinoma and chronic pancreatitis," International Journal of Experimental Pathology, vol. 75, no. 2, pp. 79-83, 1994.

[48] R. M. Senior, G. L. Griffin, C. J. Fliszar, S. D. Shapiro, G. I. Goldberg, and H. G. Welgus, "Human 92- and 72-kilodalton type IV collagenases are elastases," Journal of Biological Chemistry, vol. 266, no. 12, pp. 7870-7875, 1991.

[49] K. Guo, Q. Ma, L. Wang et al., "Norepinephrine-induced invasion by pancreatic cancer cells is inhibited by propranolol," Oncology Reports, vol. 22, no. 4, pp. 825-830, 2009.

[50] O. Takayama, H. Yamamoto, B. Damdinsuren et al., "Expression of PPAR $\delta$ in multistage carcinogenesis of the colorectum: implications of malignant cancer morphology," British Journal of Cancer, vol. 95, no. 7, pp. 889-895, 2006.

[51] N. S. Tan, L. Michalik, N. Di-Poï et al., "Essential role of Smad3 in the inhibition of inflammation-induced PPAR $\beta / \delta$ expression," The EMBO Journal, vol. 23, no. 21, pp. 4211-4221, 2004.

[52] D. A. Glauser and W. Schlegel, "The FoxO/Bcl-6/cyclin D2 pathway mediates metabolic and growth factor stimulation of proliferation in Min6 pancreatic $\beta$-cells," Journal of Receptors and Signal Transduction, vol. 29, no. 6, pp. 293-298, 2009.

[53] L. M. Toney, G. Cattoretti, J. A. Graf et al., "BCL-6 regulates chemokine gene transcription in macrophages," Nature Immunology, vol. 1, no. 3, pp. 214-220, 2000.

[54] I. Wlodarska, P. Nooyen, B. Maes et al., "Frequent occurrence of BCL6 rearrangements in nodular lymphocyte predominance Hodgkin lymphoma but not in classical Hodgkin lymphoma," Blood, vol. 101, no. 2, pp. 706-710, 2003.

[55] M. G. Tibiletti, V. Martin, B. Bernasconi et al., "BCL2, BCL6, MYC, MALT 1, and BCL10 rearrangements in nodal diffuse large B-cell lymphomas: a multicenter evaluation of a new set of fluorescent in situ hybridization probes and correlation with clinical outcome," Human Pathology, vol. 40, no. 5, pp. 645-652, 2009.

[56] A. Tzankov, A. Schneider, S. Hoeller, and S. Dirnhofer, "Prognostic importance of BCL6 rearrangements in diffuse large Bcell lymphoma with respect to Bcl6 protein levels and primary lymphoma site," Human Pathology, vol. 40, no. 7, pp. 1055-1056, 2009.

[57] A. Shvarts, T. R. Brummelkamp, F. Scheeren et al., "A senescence rescue screen identifies BCL6 as an inhibitor of antiproliferative p19ARF-p53 signaling," Genes and Development, vol. 16, no. 6, pp. 681-686, 2002.

[58] K. Holzmann, H. Kohlhammer, C. Schwaenen et al., "Genomic DNA-chip hybridization reveals a higher incidence of genomic amplifications in pancreatic cancer than conventional comparative genomic hybridization and leads to the identification of novel candidate genes," Cancer Research, vol. 64, no. 13, pp. 4428-4433, 2004.

[59] A. Perez-Rosado, M. J. Artiga, P. Vargiu, A. Sanchez-Aguilera, A. Alvarez-Barrientos, and M. A. Piris, "BCL6 represses NFאB activity in diffuse large B-cell lymphomas," Journal of Pathology, vol. 214, no. 4, pp. 498-507, 2008.

[60] M. Takada, K. Hirata, T. Ajiki, Y. Suzuki, and Y. Kuroda, "Expression of Receptor for Advanced Glycation End products (RAGE) and MMP-9 in human pancreatic cancer cells," HepatoGastroenterology, vol. 51, no. 58, pp. 928-930, 2004.

[61] A. A. Tempia-Caliera, L. Z. Horvath, A. Zimmermann et al., "Adhesion molecules in human pancreatic cancer," Journal of Surgical Oncology, vol. 79, no. 2, pp. 93-100, 2002.

[62] H. Friess, P. Berberat, M. Schilling, J. Kunz, M. Korc, and M. W. Büchler, "Pancreatic cancer: the potential clinical relevance of alterations in growth factors and their receptors," Journal of Molecular Medicine, vol. 74, no. 1, pp. 35-42, 1996.

[63] C. Y. Wu, H. L. Hsieh, C. C. Sun, and C. M. Yang, "IL-1 $\beta$ induces MMP-9 expression via a Ca2+-dependent CaMKII/JNK/c-Jun cascade in rat brain astrocytes," GLIA, vol. 57, no. 16, pp. 1775$1789,2009$.

[64] G. M. Gordon, D. R. Ledee, W. J. Feuer, and M. E. Fini, "Cytokines and signaling pathways regulating matrix metalloproteinase-9 (MMP-9) expression in corneal epithelial cellsy," Journal of Cellular Physiology, vol. 221, no. 2, pp. 402-411, 2009.

[65] L. Li, F. Q. Xing, and S. L. Chen, "Role of interleukin-1beta in regulating human cultured endometrial cell MMP-9 and TIMP3 expressions in the mid-secretory phase," Nan Fang Yi Ke Da Xue Xue Bao, vol. 26, no. 8, pp. 1143-1145, 2006.

[66] E. Greco, D. Basso, P. Fogar et al., "Pancreatic cancer cells invasiveness is mainly affected by interleukin- $1 \beta$ not by transforming growth factor- $\beta 1$,' International Journal of Biological Markers, vol. 20, no. 4, pp. 235-241, 2005.

[67] H. Takaya, A. Andoh, M. Shimada, K. Hata, Y. Fujiyama, and T. Bamba, "The expression of chemokine genes correlates with nuclear factor- $\kappa \mathrm{B}$ activation in human pancreatic cancer cell lines," Pancreas, vol. 21, no. 1, pp. 32-40, 2000.

[68] G. Solinas, F. Marchesi, C. Garlanda, A. Mantovani, and P. Allavena, "Inflammation-mediated promotion of invasion and metastasis," Cancer and Metastasis Reviews, vol. 29, no. 2, pp. 243-248, 2010. 
[69] G. G. Vaday, H. Schor, M. A. Rahat, N. Lahat, and O. Lider, "Transforming growth factor- $\beta$ suppresses tumor necrosis factor $\alpha$-induced matrix metalloproteinase- 9 expression in monocytes," Journal of Leukocyte Biology, vol. 69, no. 4, pp. 613-621, 2001.

[70] H. J. Kim, S. A. Ham, S. U. Kim et al., "Transforming growth factor- $\beta 1$ is a molecular target for the peroxisome proliferatoractivated receptor $\delta$, Circulation Research, vol. 102, no. 2, pp. 193-200, 2008. 


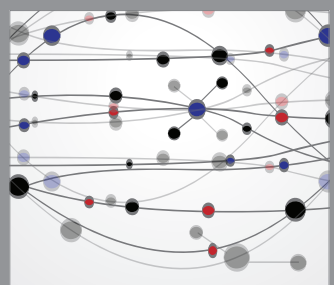

The Scientific World Journal
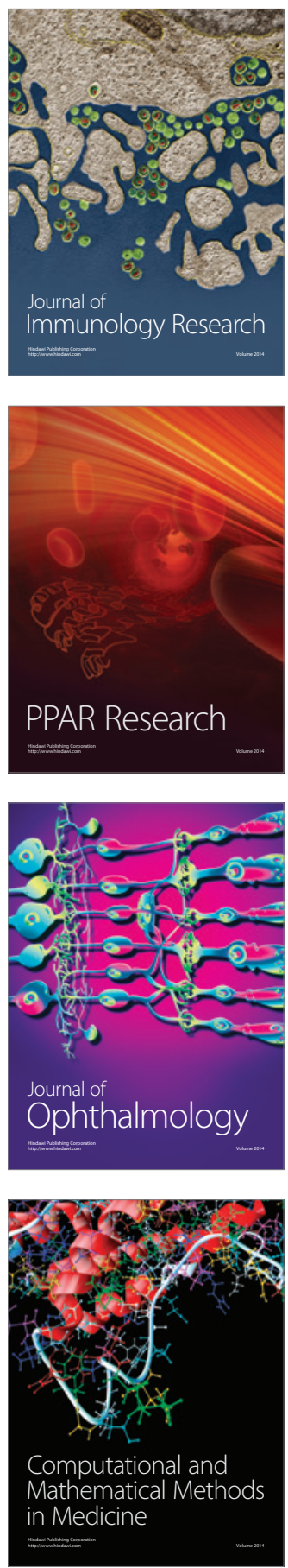

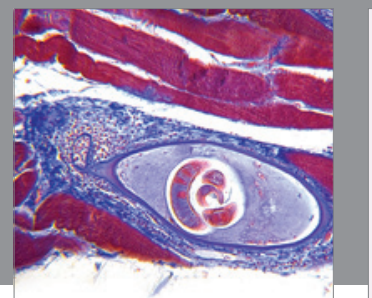

Gastroenterology

Research and Practice
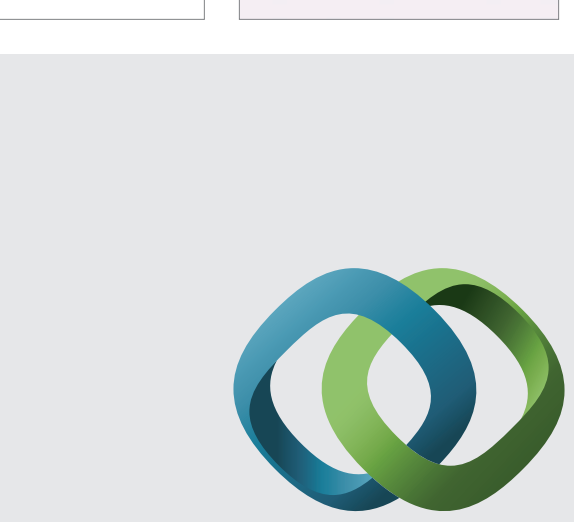

\section{Hindawi}

Submit your manuscripts at

http://www.hindawi.com
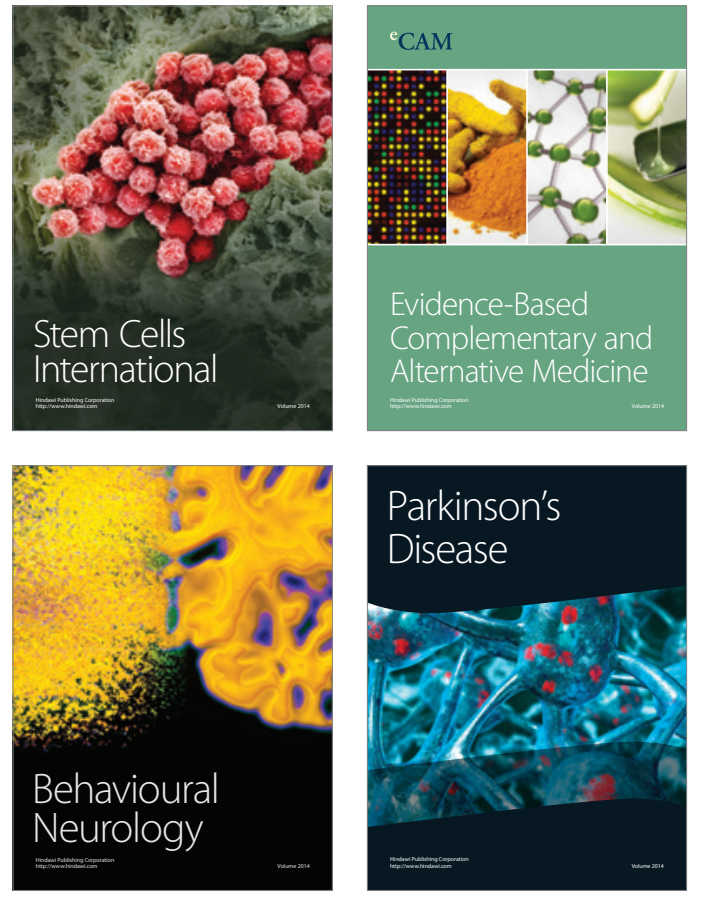
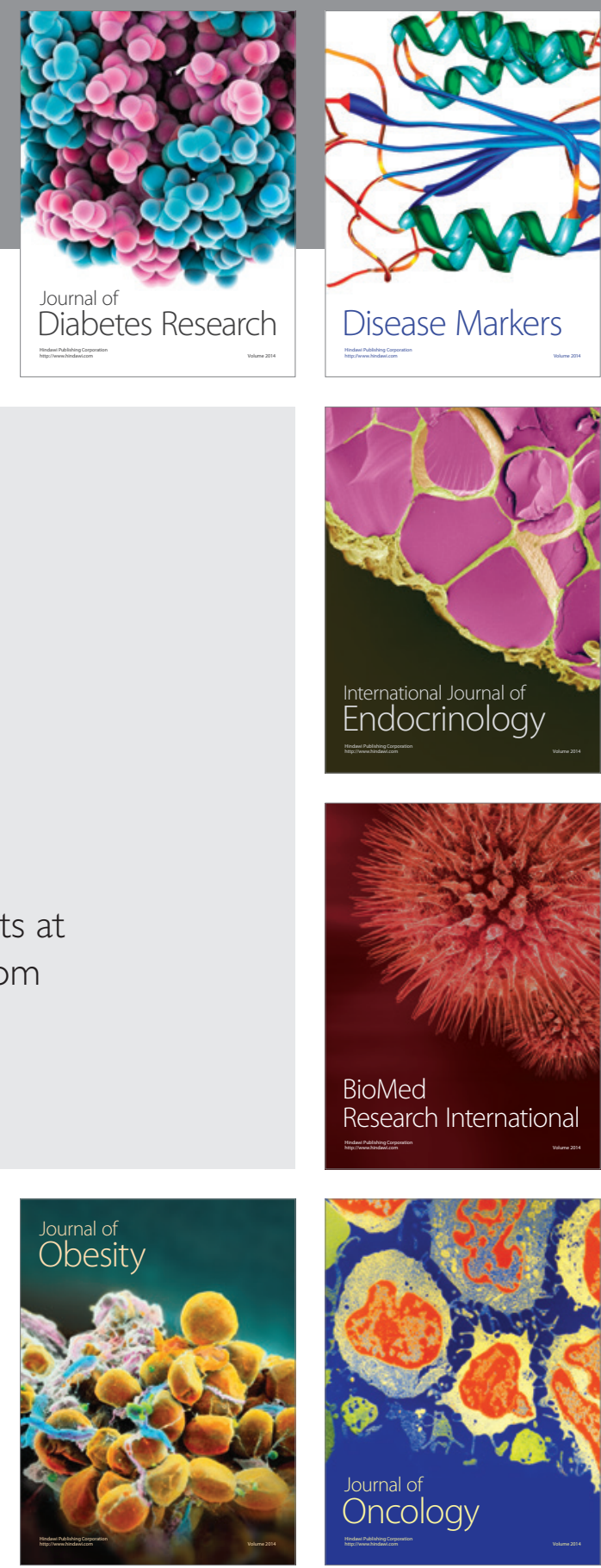

Disease Markers
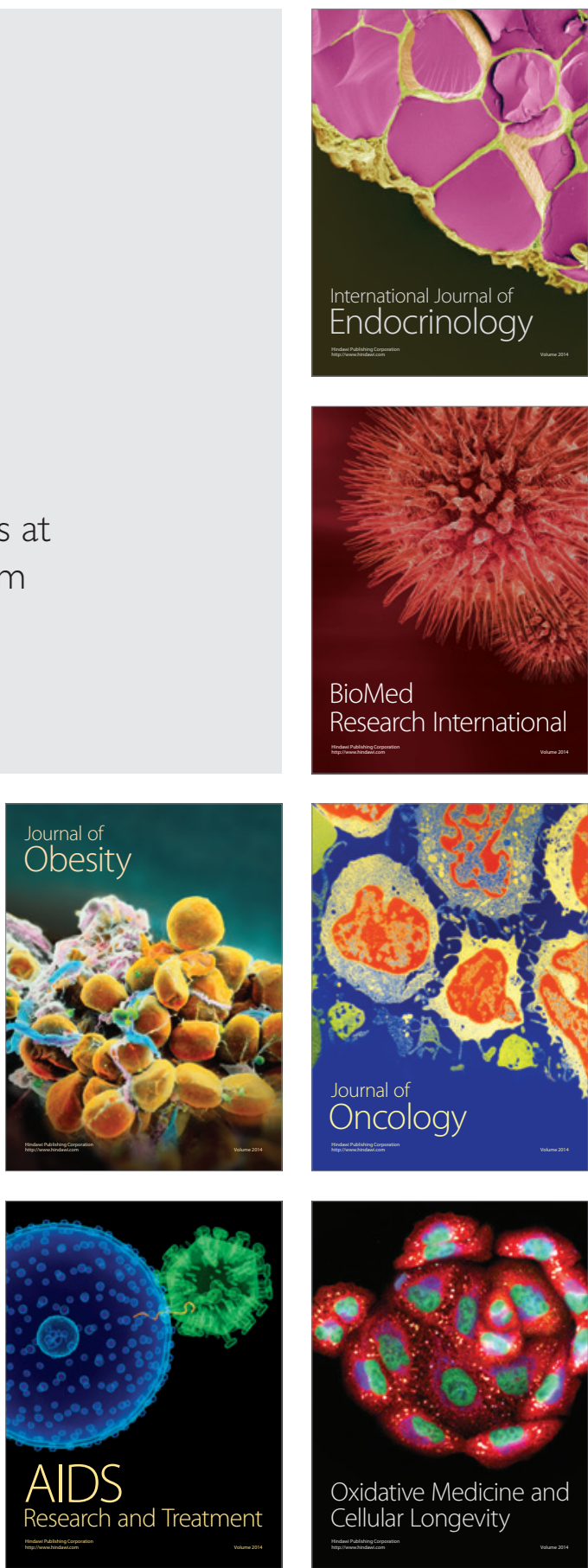